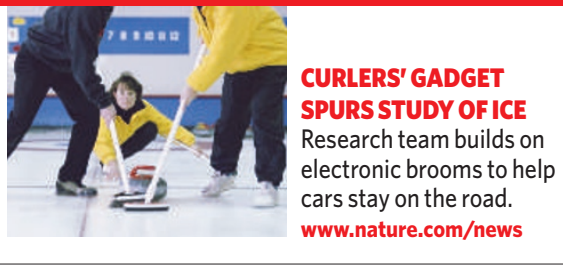

\title{
Unrest returns to confront Harvard president
}

Harvard University's president Larry Summers is facing a fresh challenge to his leadership that some say could further undermine his ability to lead the institution.

Summers provoked a storm of controversy early last year after suggesting that intrinsic differences in ability between the sexes could explain why so few women have senior positions in science. The angry

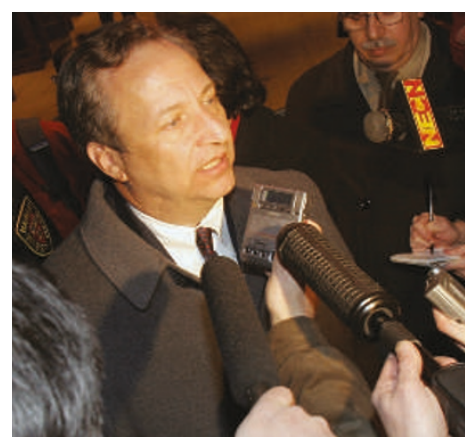

Crisis of confidence: Larry Summers' leadership is again being questioned.

Summers weathered that storm, partly by apologizing repeatedly and promising to listen to his colleagues more. But anger among the faculty continued to simmer and has now bubbled over again. The latest uprising was triggered by the resignation in January of William Kirby from his post as dean of the FAS. Kirby disagreed with Summers on some issues.

response mushroomed into a wider attack on what many describe as Summers' overbearing leadership style. It culminated in March in a vote of no confidence by the largest and most powerful of the university's faculties, the Faculty of Arts and Sciences (FAS; see Nature 434, 424; 2005).
"The faculty got very upset at the notion that the dean was being forced out," says Everett Mendelsohn, a Harvard historian of science and critic of Summers.

The brouhaha has triggered renewed attacks on Summers and calls for his resignation. The FAS is now set to vote on a second motion of no confidence at a meeting on 28 February. The ability to resolve the conflict may rest with the Harvard Corporation, the executive board that hired Summers and has the power to oust him. Last year, the corporation issued two statements in support of the university president - his bold style is said to be part $\Sigma$ of the reason they hired him - but it has so far remained silent on the current dispute. A further motion scheduled for vote at the 28 February faculty meeting calls on the corporation to intervene.

The search for Kirby's replacement may now be frozen until the situation with Summers is settled. The upheaval is also taking its toll on the university's ability to raise funds and is distracting from plans to reform the curriculum. "It's basically paralysing business above a certain level," says Richard Thomas, chair of the Classics department and a member of the faculty council.

Helen Pearson 